\title{
Primjena gnojiva na bazi fosfita u gnojidbi salate i ostalog lisnatog povrća
}

\section{Sažetak}

Fosfor je važan biogeni element za sve poljoprivredne kulture, iako se potrebe za fosforom značajno razlikuju između pojedinih poljoprivrednih kultura. Fosfor je sastavni element adenozindifosfata (ADP) i adenozintrifosfata (ATP); spojeva koji su izvor energije za sve fiziološke procese u biljci. S druge strane, gnojidba fosforom je dosta problematična, zbog niza čimbenika koji smanjuju usvajanje fosfora. Stoga, je odnedavno, kemijska industrija gnojiva ponudila nove mogućnosti u problemu gnojidbe fosforom - gnojiva na bazi fosfita. Zbog niza pozitivni h učinaka u gnojidbi, gnojiva na bazi fosfita počinju se sve više koristiti za gnojidbu poljoprivrednih kultura, pa tako i lisnatog povrća, poput salate, blitve, špinata i drugog lisnatog povrća. Osim u folijarnoj gnojidbi, fosfiti se mogu koristiti u sustavima fertirigacije. U proizvodnji gnojiva fosfiti se mješaju sa ostalim elementima, poput kalija, magnezija, kalcija ili nekog mikroelementa, te se time dobivaju visoko koncentrirana gnojiva za upotrebu u poljoprivredi. Fosfiti su specifični spojevi koji osim na ishranu biljaka imaju i ostale pozitivne učinke u poljoprivrednoj proizvodnji. Primjena fosfita efektivno povećava otpornost biljke na bolesti uvjetovane gljivicama te povećava otpornosti i na bakterijske bolesti salate. Kako je salata kultura koja se uzgaja vrlo intenzivno u vrlo uskom plodoredu, ova pozitivna svojstva gnojiva na bazi fosfita su vrlo važna.

Ključne riječi: fosfiti, fosfor, kalij-fosfit, salata

\section{Uvod}

Fosfor predstavlja važan biogeni element za sve poljoprivredne kulture, iako se potrebe za fosforom značajno razlikuju između pojedinih poljoprivrednih kultura. Fosfor je sastavni element adenozindifosfata (ADP) i adenozintrifosfata (ATP); spojeva koji su izvor energije za sve fiziološke procese u biljci. Iz tog razloga, industrija proizvodnje gnojiva je u stalnoj potrazi za novih tehnološkim rješenjima koji će rezultirati boljom i učinkovitijom gnojidbom fosforom.

S druge strane, gnojidba fosforom dosta je problematična, zbog niza čimbenika koji smanjuju usvajanje fosfora. Tu je prije svega mogućnost reakcije sa slobodnim kalcijevim ionima u tlu $\left(\mathrm{Ca}^{2+}\right)$ i tvorba netopivih kalcijevih-fosfata. Zatim, temperatura tla i količina vode reduciraju pokretljivost fosfora $u$ tlu, pa je kod temperatura ispod $12^{\circ} \mathrm{C}$ fosforni ion u obliku $\mathrm{H}_{2} \mathrm{PO}_{4}$ - praktično nepokretan. I ne manje važno, udaljenost između korijena i fosfornog iona u tlu, mora biti manja od $1 \mathrm{~mm}$, da bi došlo do difuzije fosfornog iona u biljku. Stoga, je odnedavno, kemijska industrija gnojiva ponudila nove mogućnosti u problemu gnojidbe fosforom - gnojiva na bazi fosfita.

Zbog niza pozitivnih učinaka u gnojidbi, gnojiva na bazi fosfita počinju se sve više koristiti za gnojidbu poljoprivrednih kultura, pa tako i lisnatog povrća, poput salate, blitve, špinata i drugog lisnatog povrća.

Što su fosfiti?

Fosfiti su soli fosforaste kiseline $\left(\mathrm{H}_{3} \mathrm{PO}_{3}\right)$, koji imaju specifičnu molekularnu strukturu, te za razliku od fosfata (koji su soli fosforne kiseline $\mathrm{H}_{3} \mathrm{PO}_{4}$ ) imaju jedan atom kisika manje, odnosno centralna molekula fosfora, direktno se veže na atom vodika (slika 1). U kemijskom smislu, dobivena je molekula „manje“ molekularne mase, pa je ponašanje fosfita u gnojidbi i fiziologiji drugačije od fosfata. 


\section{$\left(\mathrm{Pi}=\mathrm{HPO}_{4}{ }^{2 \cdot}\right)\left(\overline{\mathrm{Phi}=\mathrm{H}_{2} \mathrm{PO}_{3}^{-}}\right)$

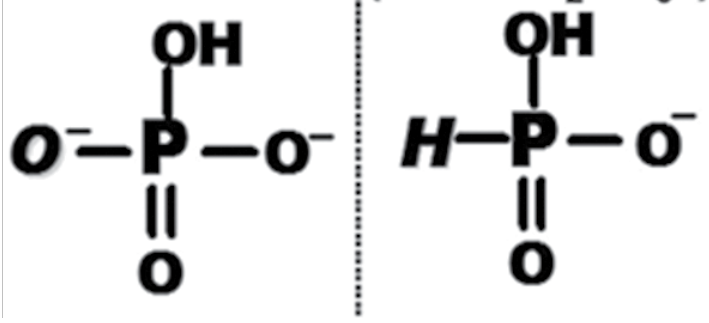

Slika 1. Molekularna struktura fosfata (lijevo) i fosfita (desno)

Prije svega, zbog manje molekularne mase, fosfiti su puno pokretljiviji u biljci (imaju tzv. sistemičan učinak, jer se mogu kretati u smjeru list-korijen i korijen-list), dobre su topivosti (na tržištu uglavnom dominiraju fosfiti u tekućem obliku, ali ima i fosfita u praškastom obliku) te brže ulaze u fiziološke reakcije u biljci. Kod primjene u tlo (kroz sustav fertirigacije) mikroorganizmi tla mogu postepeno usvajati fosfite u vlastiti metabolizam, i postupno oksidirati u fosfatne oblike, i time produžiti opskrbu biljaka fosforom na duži period; od 3 do 4 mjeseca (Adams i Conrad, 1953; Lovatt i Mikkelsen, 2006). U tlima dobre strukture i povoljnih vodozračnih odnosa, može se odvijati i proces kemijske oksidacije molekule fosfita, ali je to relativno spor i dugotrajan proces u tlu.

$\mathrm{U}$ proizvodnji gnojiva fosfiti se miješaju s ostalim elementima, poput kalija, magnezija, kalcija ili nekog mikroelementa, te se time dobivaju visokokoncentrirana gnojiva za upotrebu u poljoprivredi.

\section{Gnojiva na bazi fosfita}

Na tržištu postoje različita gnojiva na bazi fosfita, pa će u slijedećoj tablici biti prikazana svojstva gnojiva na bazi kalij-fosfita, magnezij-fosfita i kalcij-fosfita.

Tablica 1. Karakteristike gnojiva na bazi fosfita

\begin{tabular}{|c|c|c|c|}
\hline $\begin{array}{l}\text { Trgovački naziv } \\
\text { gnojiva }\end{array}$ & Koncentracija fosfora & $\begin{array}{c}\text { Koncentracija ostalih } \\
\text { hraniva }\end{array}$ & $\begin{array}{l}\text { Proizvođač } \\
\text { gnojiva }\end{array}$ \\
\hline Trafos K & $30 \% \mathrm{P}_{2} \mathrm{O}_{5}$ & $20 \% \mathrm{~K}_{2} \mathrm{O}$ & $\begin{array}{l}\text { Tradecorp Int., } \\
\text { Španjolska }\end{array}$ \\
\hline Systamag & $25 \% \mathrm{P}_{2} \mathrm{O}_{5}$ & $\begin{array}{l}\text { 3\% ukupni dušik (N) } \\
6,3 \% \mathrm{MgO} \\
0,5 \% \mathrm{Mn} \\
0,3 \% \mathrm{Zn}\end{array}$ & $\begin{array}{l}\text { Tradecorp Int., } \\
\text { Španjolska }\end{array}$ \\
\hline Fosfitec Ca & $13 \% \mathrm{P}_{2} \mathrm{O}_{5}$ & $\begin{array}{l}5 \% \mathrm{~K}_{2} \mathrm{O} \\
6 \% \mathrm{CaO}\end{array}$ & $\begin{array}{l}\text { Agrisystem Srl., } \\
\text { Italija }\end{array}$ \\
\hline
\end{tabular}

Izvor: Katalog gnojiva proizvođača Tradecorp Sl., Španjolska i Agrisystem Srl., Italija 


\section{Primjena gnojiva na bazi fosfita u gnojidbi salate i ostalog lisnatog povrća}

U gnojidbi salate i ostalog lisnatog povrća fosfiti se mogu primijeniti:

u folijarnoj gnojidbi

kroz sustav fertirigacije

u potapanju presadnica salate prije sadnje

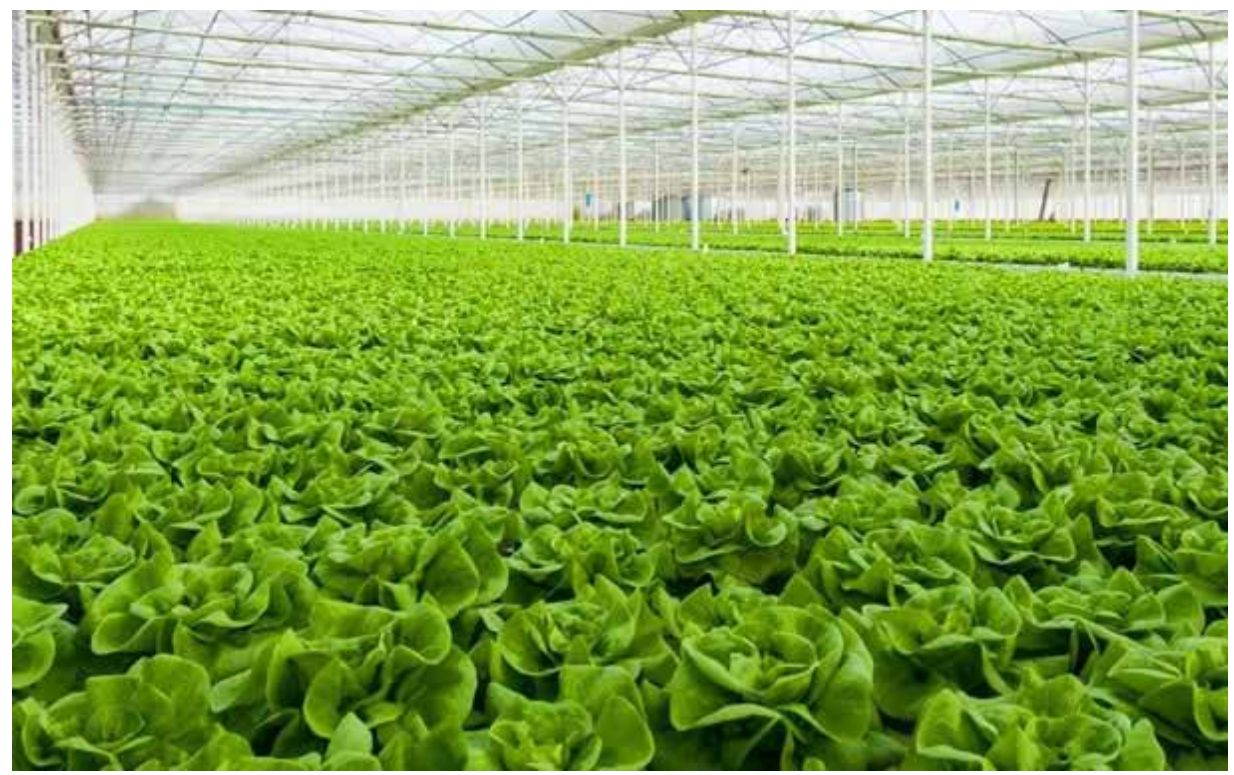

Slika 2. Uzgoj salate s dobro izbalansiranim programom gnojidbe i primjenom kalij-fosfita (autor)

Folijarna gnojidba. Kvalitetna gnojiva na bazi fosfita su gnojiva u tekućem obliku, prozirna ili slabo obojane tekućine, bez mirisa i okusa, te dobre kompatibilnosti s većinom folijarnih gnojiva ili zaštitnih sredstava. Stoga je primjena fosfita u folijarnoj gnojidbi vrlo preporučljiva.

Za folijarnu gnojidbu salate posebno se preporuča primjena kalij-fosfita (gnojivo Trafos K) tijekom jesensko-zimsko-proljetnog ciklusa uzgoja salate. Kako je salata kultura koja ima plitak korijen, manjeg volumena, upravo primjena koncentriranih fosfitnih gnojiva, koja sadrže visoke količine kalija daje dobar učinak. Kako je tijekom jesensko-zimskog perioda značajno niža temperatura zraka i manja evapotranspiracija kroz list, onda je i usvajanje kalija iz tla značajno manje. Upravo stoga, u folijarnoj gnojidbi s kalijevim-fosfitima uspješno se vrši i ishrana kalijem, što rezultira značajno većom količinom suhe tvari u listu (veća masa glavice, duže čuvanje, veća otpornost na niske temperature). Kako je tijekom jesenskog uzgojnog ciklusa moguća pojava bakterioza na listu salate, primjena kalij-fosfita može se uspješno kombinirati s gnojivima na bazi Cu-EDTA helata i time povećati otpornost salate na pojavu bakterioza.

Ukoliko tlo za uzgoj salate sadrži visoku količinu kalija, te stoga postoji mogućnost pojave kompeticije s magnezijem u tlu (i do nedostatka magnezija u listu salate) preporuča se primjena gnojiva na bazi Mg-fosfita. Na taj način će se uspješno „premostiti“ problem 
antagonizma kalij-magnezij u tlu, i salatu opskrbiti dostatnom količinom magnezija za rast i razvoj.

Prosječna doza primjene fosfita u folijarnoj gnojidbi u zaštićenim prostorima kreće se od 100-150 mL/100 L vode, dok su doze za vanjski uzgoj lisnatog povrća, nešto veće; od 200-300 mL/100 L vode. Važno je napomenuti da su fosfiti izvorno kisele otopine, te da zakiseljuju vodenu otopinu, te se mogu dobro miješati sa zaštitnim sredstvima (tablica 2).

Tablica 2. Kompatibilnost otopine kalij-fosfita (gnojivo Trafos K) sa zaštitnim sredstvima

\begin{tabular}{|c|c|}
\hline $\begin{array}{l}\text { Kompatibilnost sa fungicidima } \\
\text { (aktivne tvari) }\end{array}$ & $\begin{array}{l}\text { Kompatibilnost sa insekticidima } \\
\text { (aktivne tvari) }\end{array}$ \\
\hline Azoksistrobin & Teflubenzuron \\
\hline Betaciflutrin & Imidakloprid \\
\hline Bupirimat & Ciflutrin + Imidakloprid \\
\hline Kaptan & Ciflutrin \\
\hline Karbendazim & Abamektin \\
\hline Klorotalonil & Metomil \\
\hline Cimoksanil + Cu-oksiklorid & Endosulfan \\
\hline Cimoksanil + Famoksadon & Cipermetrin \\
\hline Cimoksanil + Folpet & tau-Fluvalinat \\
\hline Cimoksanil + Mankozeb & Flonikamid \\
\hline Cu-oksiklorid & Abamektin \\
\hline Ciazofamid & Dimetoat \\
\hline Cimoksanil & Flufenoksuron \\
\hline Cimoksanil +Folpet & Acetamiprid \\
\hline Cimoksanil +Mankozeb & Klorpirifos \\
\hline Cimoksanil +Metiram & Tebufenpirad+bifentrin \\
\hline Cimoksanil +Folpet+Mankozeb & Indoxacarb \\
\hline Difenokonazol & Bifentrin \\
\hline Dimetomorf & Karbaril \\
\hline Dimetomorf +Folpet & Diazinon \\
\hline Dimetomorf +Mankozeb & Dikofol \\
\hline \multicolumn{2}{|l|}{ Ditianon } \\
\hline \multicolumn{2}{|l|}{ Flusilazol } \\
\hline \multicolumn{2}{|l|}{ Folpet } \\
\hline \multicolumn{2}{|l|}{ Iprovalikarb+Folpet } \\
\hline \multicolumn{2}{|l|}{ Iprovalikarb+Mankozeb } \\
\hline \multicolumn{2}{|l|}{ Kresoksim-metil } \\
\hline \multicolumn{2}{|l|}{ Mankozeb } \\
\hline \multicolumn{2}{|l|}{ Mefenoksam+Folpet } \\
\hline \multicolumn{2}{|l|}{ Miklobutanil } \\
\hline \multicolumn{2}{|l|}{ Oksitioquinoks } \\
\hline \multicolumn{2}{|l|}{ Penkonazol } \\
\hline \multicolumn{2}{|l|}{ Propikonazol } \\
\hline \multicolumn{2}{|l|}{ Propikonazol +Trifloksistrobin } \\
\hline \multicolumn{2}{|l|}{ Pirimetanil } \\
\hline \multicolumn{2}{|l|}{ Spiroksamin } \\
\hline \multicolumn{2}{|l|}{ Sumpor } \\
\hline Tebukonazol & \\
\hline
\end{tabular}

Napomena: Tablica kompatibilnosti fosfita sa aktivnim tvarima zaštitnih sredstava 
odnosi se isključivo na gnojivo Trafos K (proizvođač Tradecorp SI., Španjolska), te se ne može koristiti kao tablica kompatibilnosti za ostala gnojiva na bazi fosfita zbog specifičnog stabilizatora u gnojivu Trafos K.

Gnojidba pomoću sustava navodnjavanja (fertirigacija). Fosfitna gnojiva se mogu uspješno koristiti i u gnojidbi kroz sustav fertirigacije. Kako se radi o tekućim formulacijama, primjena je jednostavna. Preporuča se samostalna primjena, bez miješanja sa ostalim gnojivima. Prosječne doze primjene su 10-20 L/ha ili 1-2 L/1.000 m². Biljka vrlo dobro usvaja hraniva iz fosfitnih gnojiva i putem korijena, a kako imaju sistemični učinak, dobro se translociraju po cijeloj biljci. U uzgoju salate i ostalog lisnatog povrća preporuča se 1-2 tretmana tijekom uzgojnog ciklusa.

Potapanje presadnica salate prije sadnje. Fosfiti se vrlo uspješno mogu koristiti i za potapanje kontejnera sa presadnicama salate prije sadnje. Za takav tretman koristi se doza od $150 \mathrm{~mL} / 100$ lit vode, te se u tu otopinu potapaju presadnice (2-4 min) 2-3 dana prije sadnje.

\section{Ostale prednosti primjene fosfita u gnojidbi salate i ostalog lisnatog povrća}

Fosfiti su specifični spojevi koji osim na ishranu biljaka imaju i ostale pozitivne učinke u poljoprivrednoj proizvodnji. Prema podacima koje navodi više autora (Guest i Grant, 1991; Griffith i sur., 1992; Niere i sur., 1994; Brown i sur., 2004; Gomez-Merino i Trejo-Tellez, 2015) primjena fosfita efektivno povećava otpornost biljke na bolesti uzrokovane gljivicama iz roda Oomycetes, posebno iz roda Peronospora (od kojih se posebno ističe povećanje otpornosti na Bremia Lactuce), Plasmopara, Phytophtora i Phytium. Lobato i sur. (2011) navode i povećanje otpornosti i na bakterijske bolesti. Kako je salata kultura koja se uzgaja u vrlo uskom plodoredu, ova pozitivna svojstva gnojiva na bazi fosfita su vrlo važna. Kako gnojiva na bazi fosfita nemaju karence (nisu označeni kao pesticidi), te nemaju okusa i mirisa, mogu se bez ograničenja koristiti u uzgoju salate, i ostalog lisnatog povrća.

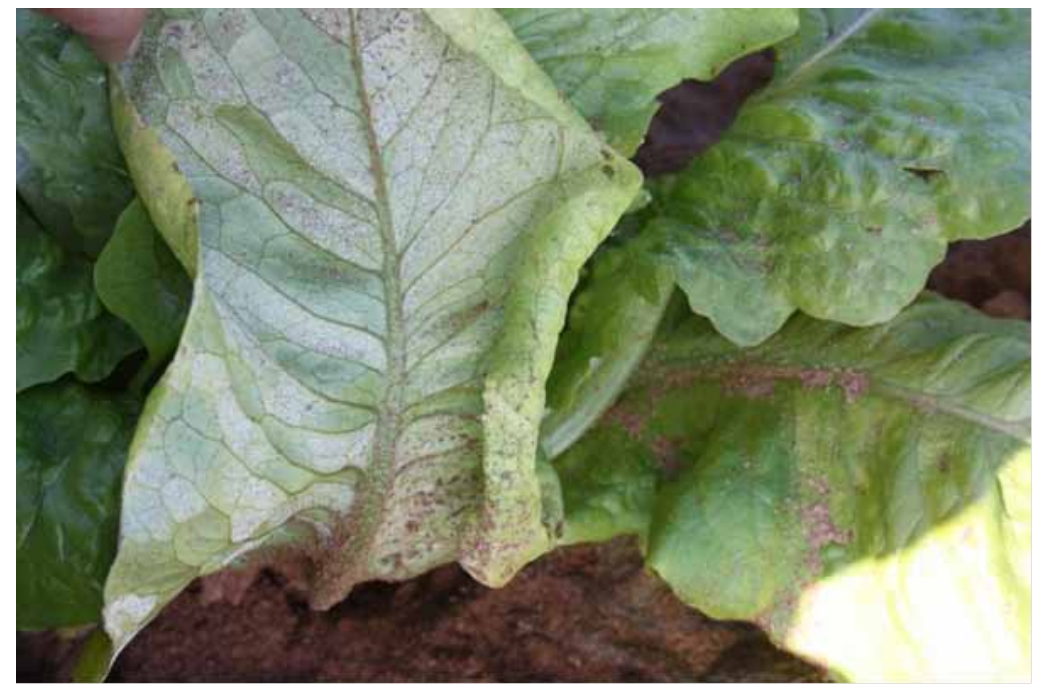

Slika 3. List salate zaražen plamenjačom (Bremia Lactuce) 
Isto tako, fosfiti imaju i biostimulativni učinak na biljke, te kako navode Gomez-Merino i Treyo-Telelz, (2015), primjena fosfita povećava usvajanje hraniva, bolji metabolizam biljaka, povećanje otpornosti na abiotske uzročnike stresa i poboljšavaju kvalitetu uroda i duže skladištenje i čuvanje.

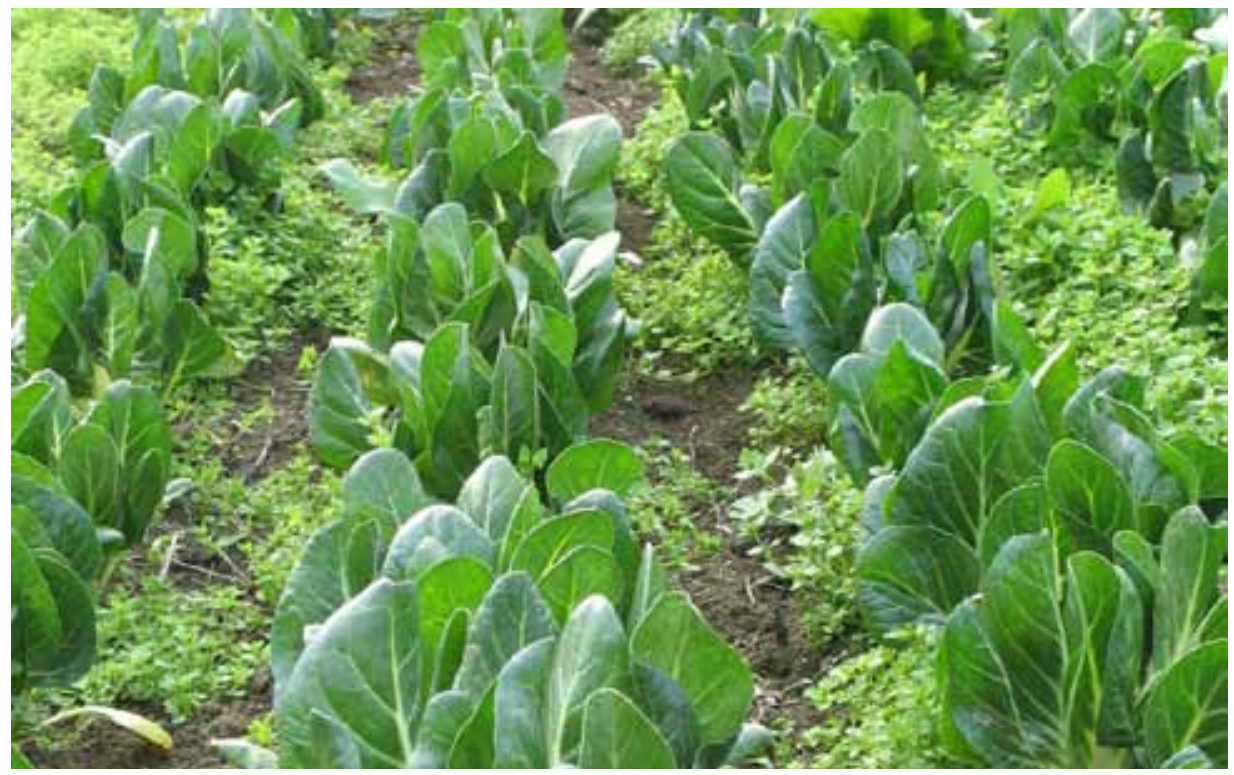

Slika 4. Blitva u plasteniku tijekom zimskog uzgoja 2016

\section{Zaključak}

Gnojiva u fosfitnom obliku predstavljaju novitet u tehnologiji gnojidbe. Radi se o posebno formuliranim spojevima gdje se u kemijskoj vezi sa molekulom fosfita nalazi vezan određeni kation; biljno hranivo. Najčešće je to kalij, pa je većina gnojiva na bazi fosfita u obliku kalijevog fosfita, ali isto tako, umjesto kationa kalija, na molekulu fosfita mogu se vezati i ostali kationi (kalcij, magnezij, cink, bakar). Za primjenu u gnojidbi salate i ostalog lisnatog povrća, fosfiti ostvaruju višestruku korist: poboljšavaju gnojidbu biljaka ali isto tako povećavaju otpornost biljaka na razne bolesti (vrlo česte u uskom plodoredu uzgoja salate) i imaju biostimulativni učinak. Stoga se preporuča redovna primjena fosfita u gnojidbi salate i ostalog lisnatog povrća, prema navedenim tehnološkim smjernicama u ovom članku.

\section{Literatura}

Adams, F., Conrad. J.P. (1953). Transition of phosphite to phosphate in soils. Soil Science 75, 361-371.

Brown, S., Koike S.T., Ochoa O.E., Laemmlen F., Michelmore R.W. (2004). Insensitivity to the fungicide fosetyl-aluminum in California isolates of the lettuce downy mildew pathogen, Bremia lactucae. Plant Disease 88, 502-508.

Gomez-Merino F.C., Trejo-Tellez L.I. (2015). Biostimulant activitiy of phosphite in horticulture. Scientia Horticulturae $196,82-90$

Griffith, J.M., Davis A.J., Grant B.R. (1992). Target sites of fungicides to control oomycetes. In: Koller, W., ed. Target sites of fungicide action, Boca Raton, FL, CRC Press, Inc., 69-100

Guest, D., Grant B. (1991). The complex action of phosphonates as antifungal agents. Biological Reviews 66,159-187. Lobato M.C., Machinandiarena M.F., Tambascio C., Dosio G.A.A., Caldiz D.O., Daleo G.R., Andreu A.B., Olivieri F.P. (2011). Effect of foliar application of phosphite on post-harvest potato tubers. Eur. J. Plant Pathol. 130, 155-163.

Lovatt C.J., Mikkelsen R.L. (2006). Phoshite fertilizer: what are they? Can you use them? What can they do? Better 
Crops 90, 11-13.

Niere, J.O., DeAngelis G., Grant B.R. (1994). The effect of phosphonate on the acid-soluble phosphorus components in the genus Phytophthora. Microbiology 140, 1661-1670.

\title{
The application of fertilizers based on phosphite in lettuce and other leafy vegetables fertilization
}

\begin{abstract}
Phosphorus represents an important biogenic element for all agricultural crops. Although phosphorus requirements differ significantly between individual crops, the phosphorus requirement is very important because phosphorus is a constituent element of adenosine-diphosphate (ADP) and adenosine-triphosphate (ATP); compounds that are source of energy for all physiological processes in the plant. On the other hand, fertilization with phosphorus is quite problematic due to a number of factors that reduce the uptake of phosphorus from soil. Therefore, the chemical fertilizer industry has recently offered new opportunities for phosphorus fertilization - phosphite based fertilizers. Due to a number of positive effects on fertilization, phosphite based fertilizers are increasingly being used for the fertilization of agricultural crops, as well as leafy vegetables such as lettuce, leaf beet, spinach and other leafy vegetables. Except in foliar fertilization, phosphites can be used in fertigation systems too. In the production of fertilizers, the phosphites are mixed with other elements such as potassium, magnesium, calcium or some microelement, thus obtaining highly concentrated fertilizers for use in agriculture. Phosphates are specific compounds that, besides plant nutrition, have other positive effects in agricultural production. The use of phosphite effectively increases the resistance of the plant to diseases caused by the fungus and increases the resistance to bacterial diseases of leaf. As a lettuce production is very intensive, these positive properties of phosphite based fertilizers are very important.

Key words: phosphite,phosphorus, potassium-phosphite, letucce
\end{abstract}
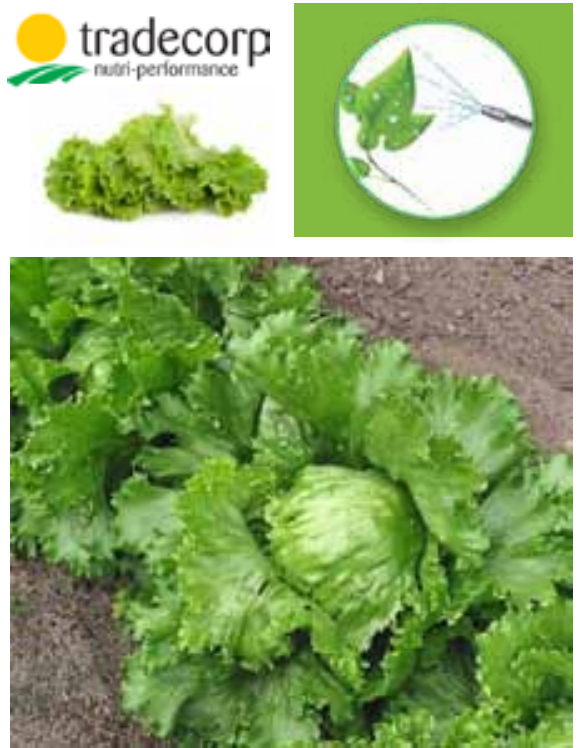
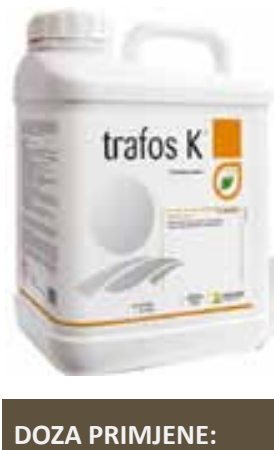

\section{Plastenici:}

100-150 mL/100 lit.

vode

Otvoreno polje:

$150-200 \mathrm{~mL} / 100$ lit.

vode

\section{Folijarna gnojidba salate}

Visoka koncentracija fosfora $(\mathrm{P}) \mathrm{i}$ kalija (K)

Podiže prirodnu otpornost salate na sve gljivične bolesti 